\title{
Forward to the 1980s: US strategic trade in the world order
}

\author{
Thomas Furse $^{1}$ (D)
}

Accepted: 4 June 2021 / Published online: 17 June 2021

(c) The Author(s), under exclusive licence to Springer Nature Limited 2021

\begin{abstract}
This paper argues that the Trump administration adopted a politicized form of strategic trade policy in its approach to international trade. This strategy combined deregulation, free trade, subsidies, export promotion, and various forms of protectionism. These trade instruments were ideologically incoherent, but the administration designed them so domestic firms could compete against foreign ones and so the US to dominate the world order. These policies came from debates in the 1980s when the Reagan administration created a strategy to stem manufacturing decline as European and Asian economies grew. When we see the 1980s as a confrontational moment for the USA in the world, we can better understand the origins and practice of the Trump administration's strategic vision on trade policy in the $2010 \mathrm{~s}$.
\end{abstract}

Keywords Trump $\cdot$ Strategic trade $\cdot$ Free trade $\cdot$ Protectionism $\cdot$ Multilateralism

\section{Introduction}

The election victory of Donald Trump prompted some to see a halt or even a loss of openness of globalization. His 2016 campaign and administration appeared to illustrate a preference for an inward-looking nativism over international liberal ideals. His break with free trade agreements and global governance and his disdain for some allies seemed particular to his ideology and the capture of the Republican Party by Tea Party activists, the Christian Right, and a right-wing anti-immigrant sentiment. These factors are important markers of what makes the Trump administration. However, this argument ignores the fact that the administration's trade policy has substantial crossover with the strategic trade policies of the 1980s. These older strategic trade policies sought to promote domestic firms over foreign ones, promote exports, and tried to keep domestic intellectual property secret from foreign

Thomas Furse

Thomas.furse@city.ac.uk

1 International Politics, City University of London, Northampton Square, Clerkenwell,

London EC1V 0HB, UK 
competition. There is a precedent for what Trump did with trade renegotiations and trade policy in general.

Strategic Trade Theory (STT), developed in the 1980s, outlined how governments could be active in national economies even as they began significant deregulations. It showed how and why governments selectively used protectionism, export limits, and R\&D subsidies to shift profits to domestic firms (see Brander and Spencer 1983, 1985; Stegemann 1989; Richardson 1990; Krugman 1995). Governments curated this strategy so national firms could compete in an oligopolistic international market. In this perspective, the government acts to improve market competition and can often develop a national industrial policy.

The Trump administration did not consciously adopt Strategic Trade Theory outright. Rather, the administration politicized a version of it and tuned it to fit their electoral messaging about the trade deficit and the loss of manufacturing jobs, to appeal to voters and donors, and to achieve political and foreign policy objectives. Its own trade policy developed the main features of the Reagan administration's trade policy. They both accepted that an oligarchy of major American, Chinese, Japanese, and some European firms dominated the world economy, and sought to support domestic-based firms through a variety of trade instruments. These instruments included the administration's willingness to use tariffs; coercion against allies and adversaries at the same time; funding the Export-Import Bank; subsidizing manufacturing firms to 'reshore' their profits and operations; criticism of the World Trade Organization; often favoring bilateralism over multilateralism; closed contract bidding; commitments to purchase; fiercely protecting intellectual property and securing supply chains; and the more conventional instruments of deregulation, tax cuts, and negotiating free trade agreements. A guiding motivation for these instruments was a deep fear of rising powers, Japan in the 1980s and the EU and China in the 2010s. This fear justified this ideologically contradictory menu of trade instruments to compete in the world. This article shows that although the Trump administration departed rhetorically from some administrations before it, it was not outside the boundaries of an uneven bipartisan consensus about US trade policy strategy. The parallels between the Reagan and Trump administrations are particularly strong and are the central case studies for this article.

Both these administrations constructed an ideologically incoherent trade strategy, but one that was coherent in its aim to make domestic firms competitive in the world economy. These multiple tools are rooted in how the 'neoliberal' state functions in its reinforcement of market competition in the economy (Wraight 2019). Democrats and Republicans in the legislative and executive branches crafted tariffs, non-tariff barriers, free trade agreements, demanded reciprocal market access and regulatory standardization to consolidate US economic position in the world order. This hybridity facilitated deeper interconnections between the US state and the private sector. These instruments were often coercive in intention and practice. The administrations used them both unilaterally and in a variety of bilateral and some multilateral forums. They sought to ensure US global dominance amidst competition from their European and Asian allies and to please and placate voters and donors. The Trump administration has adopted these policies and intensified them to compete in the world, particularly against China. 
China's economic and military power has captured the attention of the US strategic community (see Meijer 2020). Commentators and governments worldwide questioned the Trump administration's simultaneous antagonism toward both its allies and China. If China was the real national security threat, why did the administration punish its allies over trade? Why not form a multilateral forum of free-market democracies to unite against China? For the Trump administration, American alliances were not founded to contain China's ambitions. As the US competed with China, the administration argued that it needed more manufacturing industries of its own, secure supply chains, foreign markets to be more open to US exports, and cut Chinese influence from its supply chains. The US, from this mindset, cannot compete against rivals if it does not have a domestic industrial base and secure supply chains. It must be coercive against allies and incentivize them to act in US interests to enforce the US-led hierarchy to compete in the world. Similarly, the Reagan administration, despite the Soviet Union's military power and threats of nuclear war, still coerced its allies-West Germany and Japan-over trade (see Vernon 1982, 490-502; Brody 1998, 96-97; Wraight 2019). A common threat did not extinguish an American desire to redress its allies over trade or military commitments.

This article starts with a broad survey of US strategic trade policy in the 1980s. Its purpose is to show how the US state has honed a collection of trade instruments and perspectives to consolidate US power in the world. The second section examines the Trump administration's strategic judgement on securing supply chains, the Export-Import Bank, donor interests, and its use of deregulation and subsidies. It argues that the Trump administration competed with rivals through coercively encouraging allies into its orbit. The third section is a discussion about how the administration's strategy toward multilateral and bilateral trade pacts seeks to maintain American economic power compared to partners, rather than any ideological attachment to free trade. The last section looks at how the Trump administration, through the US Trade Representative, operated at World Trade Organization to slow China's rise and rebuild globalization.

\section{Strategic trade instruments in the 1980s}

In some senses, the Trump administration followed Republican orthodoxy. It promoted business deregulation, cut taxes on corporations, favored social conservatism, and boosted the defense budget (Herbert et al. 2019). His brazen tariffs on trading partners at first seems a contrast to free-wheeling capitalism and an ideological inconsistency in an inconsistent president. This conclusion partly comes from a wide ideological division between free traders and protectionists. For the former, the primacy of free-market economics takes hold, while the latter caters to the narrow needs of domestic industries. Free trade travels with ideas about multilateralism, openness, and innovation, whereas protectionism is often connected to unilateralism, special interest lobbying, and xenophobia. However, this much-repeated division provokes a question-has the US practiced these simultaneously?

Successive administrations have used tariffs, fair trade, export subsidies, and asymmetric free trade agreements at the same time to improve US competitiveness 
against allies and adversaries. In the 1960s and 1970s, there were some early signs of this attitude, but the 1980s showed a much deeper concern among trade strategists about American firms competing in the world. The Reagan administration was particularly alert about maintaining American power in the global economy in the face of Japanese competition (Meinderts 2020). Even as Reagan advocated free trade, the administration and congress enforced trade barriers on imported textiles, auto parts, semiconductors, motorcycles, sugar, and steel (see more Wraight 2019; Brody 1998, 95-97). Although the Cold War tightened security alliances, Republicans and Democrats in congresses pressured allies and used protectionism and at times free trade to bolster domestic firms at the expense of foreign firms.

In the 1970s and 1980s, Congress passed a series of laws that gave unilateral powers to the President and the US Trade Representative (USTR). The 1974 Trade Act and the Trade Agreements Act of 1979 implemented and refined Sect. 301 which gave the USTR authority to investigate foreign trade practices that potentially damaged US commerce and to implement tariffs and non-tariff barriers (Bhagwati and Patrick 1991). Section 301 was designed to counter unfair trade but Reagan and Trump's use of it illustrates how it became a coercive tool of protectionism (Meinderts 2020; Wraight 2019). The executive branch gained significant power to act on other states as they saw the international market becoming more competitive. The president could now directly retaliate against foreign countries and protect the domestic industries as Japan and West Germany were beginning to usurp US trade dominance in manufacturing.

In the 1980s, the menu of strategic instruments was substantially augmented. Within General Agreements on Tariffs and Trade (GATT), the US, along with Canada, the ECC, and Japan, formed the multilateral 'Quad' to coordinate trade policy and curtail demands from elsewhere. This became a more formal alliance in 1981. This occurred as the US negotiated its first two free trade agreements with Israel in 1985 and Canada in 1988. These multilateral and bilateral endeavors were mixed with unilateralism and demand for free reciprocal trade. Congress passed the Omnibus Tariff and Trade Act (OTTA) in 1984 with 368-43 and 96-0 majorities (Smith 2011). OTTA meant the president had greater determination in deciding whether countries were protecting US intellectual property and altered the president's 'fasttrack' procedures so congressional committees (who were often protectionistminded) would have more oversight over bilateral agreements (Rushing 2020). It gave the Commerce Secretary authority to enforce export restrictions on steel pipes from the European Community to the USA (US Congress 1984, 36). It also cut duties on some imports and supported working rights in foreign countries, so they were less able to undercut American workers. Rather than being the result of mismatched objectives, these legislative outcomes were how the US state organized its international trade policy to compete against European and Asian allies.

This ideologically hybrid strategy continued in 1988 when the Omnibus Foreign Trade and Competitiveness Act passed with overwhelming bipartisan majorities. The act made amendments to Section 301 so that the USTR had greater authority to list unfair trading partners if they appeared to damage the US and global commerce. These countries would have to change their practices, or the US would authorize retaliation. Even as the US reduced its tariffs as a signatory to GATT, it used 
quotas and 'Buy American' for government procurement to limit new imports hurting American firms (Eaton 1995, 123). Thus, the US strengthened its instruments for unilateral coercion in trade and protectionism short of tariffs as it signed up to freer trade and multilateralism in the global economy. In 1983, for instance, the administration simultaneously cautioned Japan over its trade restrictions and imposed tariffs on Chinese textile imports (Clines 1983; Wren 1983). This trade strategy meant that free trade and protection were not mutually exclusive ideological positions but entwined in similar interpretations of what the US ought to do to consolidate its economic dominance. Some even saw that US unilateralism in Section 301 strengthened multilateralism as countries sought to standardize laws (Rajah 2018).

Despite these legislative measures, congressional and presidential frustration with US competitiveness in the world did not abate during the 1980s. Even the polarized political atmosphere between President Reagan and the Democratic-led House did not stop all bipartisanship on trade policy. Two Democrats wrote the Exon-Florio Amendment (1988) that gave Reagan a stronger hand in blocking foreign investment in the USA. He still had some difficulties, however. Reagan tried to steer a plan through a largely pro-protectionist Congress to reduce the trade deficit through subsidizing exports, lowering the value of the Dollar, and subtly threatening other states that the US would withdraw bank aid if they did not stop restricting trade (Weinraub 1985). The bipartisan consensus rested on an uneven but broadly shared interpretation that international trade was competitive with oligarchic firms and that the USA must exploit allies and adversaries to maintain its position. The ideals of an open and fair liberal international space were not at the forefront of US trade policy decisions.

These trade acts came from a politicized form of strategic trade that captured the executive and legislatures in the 1980s (Stegemann 1989; Nollen and Quinn 1994). Strategic trade theory meant the government had a role in the economy even as it deregulated and used protectionism and subsidies to support American firms. By the 1980s, US industrial companies were more export-oriented than they were in the 1960s. They were competing well against Japanese and European ones (National Intelligence Council 1982). But for many in congress and in administrations these firms, and therefore the US, may not keep its competitive edge for long. This looming threat suggests that the US-led hierarchy could not withstand even close allied parity with US economic power. The Reagan administrations and congresses in the 1980s looked at export or production subsidies to lower the costs for firms so they could compete in the world (see further Brander 1995, 31). The strategic trade policy meant there was a close intersection between the state apparatus and American corporations. The regulatory environment in the 1980s decreased government oversight, even as it controversially supported American companies in the world through subsidies, funding the Export-Import Bank, and loaning to Central American states so they could import US products (Farnsworth 1983; Noble 1984; Weinraub 1985).

These trade acts, international agreements, and domestic discussions created an intellectual milieu that successive administrations, and in particular the Trump administration, have embraced to compete in the world. The point here is that this hybrid trade policy originated during the 1980s as US firms started needing to export to maintain profits. It is an initial toolkit that the Trump administration used 
to reposition US power in a world order that appeared to them to be traveling away from American economic interests in the 2010s. To support its demand for reciprocal market access, the US has used Section 301130 times against the EU, Canada, Japan, South Korea, Brazil, and China (Schwarzenberg 2020a, b). This coercive, even zero-sum, behavior and Section 301 is characteristic of what has been called 'aggressive unilateralism' which intended to make US firms more competitive and prise open foreign markets (Bhagwati and Patrick 1991).

\section{The Trump administration's strategic judgement in trade policy}

Allies lambasted the Trump administration for its immediate bellicosity against the tides of free trade and globalization. Many leaders regarded the administration as protectionist or even isolationist. Allies in Europe and Asia found that his harsh rhetoric and relishing at coercion in trade policy on campaign was an early warning for the future. Criticism abounded when the Trump administration withdrew from the Trans-Pacific Partnership (TPP) three days into the presidency. The administration appeared to be withdrawing from the world, and for some, allowing China greater layaway in the Pacific. The US seemed to lose a significant strategic asset to shape norms and rules in the TPP (see Dian 2017). The USA punished allies and China. Why not use the US diplomatic network and multilateralism to unite allies against China?

This argument, however, misunderstands how the US competes against rivals in trade. The strategic content of the administration's trade policy and its attitude to multilateral agreements has come largely from a consistent domestic bipartisan suspicion that other states are cheating or could usurp American dominance. The Trump administration's view of trade is not a significant strategic departure from how the US conducted trade in the 1980s. The administration was not wedded to the notion of the international order springing from benign cooperation or meditations about limiting the ugliness of national self-interest. Like the Reagan administration, Trump sought to activate American dominance in some form or other to protect domestic businesses, sectors of the economy, or win favors with sections of the electorate. To compete in the world, the Trump administration argued that it must rebuild its manufacturing industries and open foreign markets for US exports.

When faced with serious geopolitical and economic competition, the US has not instinctively turned just to liberal or benign internationalism to resolve its problems. Its strategy has been to enforce a hierarchy and to pull other states into its orbit. The Trump administration's critique of globalization targeted how global supply chains in manufacturing industries were now too insecure for the US to compete. Arresting the decline of American manufacturing, particularly in metals, became a national security issue. At the root of this insecurity is the fear that the US was losing time against the rising tide of emerging powers. From the administration's strategic standpoint, to contain China the US must consolidate its industrial capacity within its borders, or at least within North America (Department of Defense 2018). This strategy explicitly ties the fortunes of the US in the world order to the material abundance of precious metals and raw materials needed for the military and manufacturing. 
The Trump administration's refocusing on guarding supply chains is reminiscent of the 1988-1989 Defense Authorization Act that barred foreign firms from R\&D contracts for Strategic Defense Initiative (SDI) (Pamuk and Shalal 2020; also see Nollen and Quinn 1994, 491, 498). The government had to choose US firms if they could adequately perform the task. The 1974, 1979, and 1984 trade acts strengthened powers to curtail economic espionage by private companies that had close relations with foreign governments. In the 1980s, American intelligence feared that China, Soviet Union, Japan, and France were stealing and copying its technology. In 1979, Congress enacted the Export Administration Act which restricted US exports to any country that would threaten US security and defense. Even toward the end of his presidency, Obama signed the overwhelmingly popular bipartisan Defend Trade Secrets Act in 2016 that strengthened the legal power of an owner who believes a trade secret has been misappropriated.

The Trump administration has similarly used these instruments to secure supply chains for the US military and manufacturing industries. The administration used the Department of Commerce's Bureau of Industry and Security (Bis) to restrict exports to specifically hurt Chinese technology firms. The Commerce Department sought to remove any US-made software in Huawei equipment. Trump's desire to protect and enhance domestic firms in the international market comes from a preexisting administrative environment. The political-corporate network, specifically lobbyists and party donors in Washington D.C. have at times influenced the shape of US trade policy (Waterhouse 2014). Dreiling and Darves (2011) argued that American corporations have largely encouraged international free trade through using their professional networks and lobbying efforts to achieve political influence over trade policy. Often however, the US used free trade when it could dominate trade negotiations and give US corporations access to foreign markets (Ann Elliot 2017). Promoting free trade and securing supply chains through protectionism and restrictions were not ideological opposites, but tools to bolster US power.

Figures in the Trump administration maintained ties with industries that were not unabashedly pro-free trade as well as those that were. Robert Lighthizer, the USTR, argued that Covid-19 demonstrated how weak US supply chains were and how outsourcing hurt American workers (2020b). As a result, the administration used a hybrid strategy of 'aggressive unilateralism,' subsidies, protectionist measures, overtures to free trade, tax cuts, and deregulation to reshore industry back into the USA. Several executive orders directly encouraged firms to move production to the US as well. Trump's pursuit of tariffs on steel and aluminum imports caused ire among long-time Republican donors such as the Koch brothers but was actively sought after by others. US steelmakers, such as AK Steel, US Steel, and Nucor donated to proTrump PACs to continue tariffs on metals (Tankersley 2018). Nucor funded Peter Navarro's 2011 film Death by China which promoted protectionism to defend US industrial power. The Republican Party, the conservative intellectual environment, and its corporate network are not fully aligned with one another about free trade and protectionism. This explains why the Trump administration was acutely sensitive to foreign competition, and developed multiple, ideologically contradictory instruments. In essence, the Trump administration used 1980s-style trade acts to protect 
its domestic firms from foreign competition as it tried to keep those company's profits and jobs in the USA.

The immediacy of China's rise to being near US parity in economic size was an organizing principle within the Trump administration, and it meant he rushed through trade policy measures and national industrial policy. He combined deregulation and subsidies through executive orders to 'reshore' industry into the USA. In Executive Order 13921, Trump sought to support the American fishing industry through deregulation, combating illegal fishing, and furthering 'fair and reciprocal trade in seafood products' (EO13921). Executive Order 13922 went broader into protecting the US 'domestic industrial base' specifically from China and expanding production of 'strategic resources,' such as medical supplies and materials for national defense. The administration designed this EO to deepen the content of EO 13603 (2012) and EO 13911 (2020) which sought to secure defense and medical resources (see EO 13922). At the time, Trump's chief economic advisor, Larry Kudlow, and Congress independently mulled the idea that the government would subsidize the costs of moving operations from China to the US (Institute of Export and International Trade 2020; Shalal, Alper and Zengerle 2020). These executive orders and ideas suggest that there was a politicized strategic trade policy that combined tax cuts, deregulation, and subsidies with the explicit purpose of encouraging domestic production for export. Making US firms competitive in the world was the priority, not any ideological attachment to a policy.

Both Trump and Reagan sought to increase funding for the Export-Import Bank to encourage US firms to export (Farnsworth 1983; Warmbrodt 2019). In both 1983 and 2019, Reagan and Trump faced conservative infighting about funding the government agency. In both cases, figures within the administrations-Larry Kudlow and Peter Navarro in Trump's administration and Bill Brock and Malcolm Baldrige Jr. in Reagan's administration-had to justify spending money on what many other conservatives argued was tantamount to government interference in the economy. As libertarian-leaning Republicans pushed to defund the agency; the manufacturing lobby pushed to fund it. This difficulty is reflected in Trump's oscillation between supporting and threatening to shutter the agency (Swanson and Kaplan 2017). This too mirrors Reagan's swings between praising the agency and cutting its funding at different moments (de Rugy 2014). These intra-conservative debates about trade strategy from the 1980s and 2010s illustrate how parallel the strategic vision of trade policy is in these two decades. In 2019, Trump signed the Democraticled but broadly bipartisan appropriations bill, H.R. 1865, that kept funding for the Export-Import Bank.

The 1980s was a formative decade for Trump's initial interest in politics. Trade antagonism between the US and Japan, rising foreign competition and widespread concern about US decline spurred Trump's 1987 advert in the New York Times (Trump 1987). The full-page advert argued that Japan, Saudi Arabia, and others were cheating the US out of money and that tariffs would rebalance the relationship. Trump's frequent complaints about the currency value of China's Renminbi and the Euro is akin to the discourse in the 1980s about the Japanese Yen (Miller 2018). The Trump administration threatened security protection to gain trading concessions from South Korea and Japan. And the administration excluded Japan from 
a 'whitelist' that exempts countries from undergoing a review of its investments in American technology (Segawa 2020). This behavior attempted to consolidate US domestic industrial base and narrow the trade deficit as it engaged in fierce competition with China. It is a form of hierarchy-building amongst itself and its allies so it can compete. In their strategic mind, the US cannot compete if it is so ensconced with its allies.

Trump's coercion of allies and China in the 2010s fits into his interpretation of strategic trade policy in the 1980s. At this time, many commentators argued that Japan had become a geo-economic, even civilizational rival (see Miller 2018; Tuathail 1996, 242-249). The military and economic strategic communities broadly considered its growth to be a national security threat. In 1982, American intelligence analyzed the Japanese economy and tried to dispel the assertion that 'Japan's recent dramatic high-technology accomplishments foreshadow the end of US technological preeminence' (National Intelligence Council 1982, iii, 4; Brody 1998, 96-97, 99). They concluded that Japan concentrated on certain industrial sectors, like the automotive sector, steel, industrial machinery, electronics, and ships which led to its growth rate, but limited its reach if these markets faltered.

Nevertheless, trade tensions continued because administrations feared that near parity could upend US power. Unilateral, bilateral, and multilateral instruments contained Japan. The US-led the Plaza and Louvre accords with other advanced economies in 1985 and 1987 to stem the devaluation of the Japanese Yen and the Deutschmark relative to the US Dollar. In conjunction, Reagan unilaterally put 100 percent tariffs on some Japanese electronics because the country was not complying with a 1988 agreement that opened more of its market to US-made semiconductors and restricted selling these wares to third parties (Meinderts 2020). The administration carried out this action to 'enforce the principles of free and fair trade' (Boyd 1987). The US issued 'voluntary export restraints' in 1985 to limit Japanese exports to the US and further pressure the country while it provided export subsidies so US firms could be competitive and to counter losses to business against trade partners who the administration deemed protectionist (Weinraub 1985). The threat of North Korea and the Soviet Union in northeast Asia did not stop the USA from demanding trade concessions from Japan.

The Trump administration adopted a similar strategy to buy time against what they saw as China's rising counter-hegemony in East Asia. They were not alone in this, even during the Asian financial crisis in 1997-98, the US halted Japan's Asian Monetary Fund initiative because it feared that it would supplant the US economic clout and the IMF in the region. US fear of economic decline has been a consistent feature in American politics, particularly in the debate over its international role (see Zarakol 2019; Zanchetta 2015). The Trump administration, alongside previous administrations, tapped into a bipartisan notion (among politicians and voters) that the US was in decline in the world because it was not protecting its manufacturing industry. Many figures in the Trump administration were fearful that declining US manufacturing was directly connected to China's industrial rise (Pence 2018; Lighthizer 2020a). Dennis Shea, before Trump 
appointed him US ambassador to the WTO and as deputy USTR, wrote approvingly of stopping Chinese firms from investing and buying US firms for national security reasons (Shea and Bartholomew 2016). Figures in the Biden administration have echoed similar concerns (Rice 2017; Blinken 2017). In this strategic vision, time is running out for America's ability to wield significant power in the world and to maintain a US-led hierarchy.

\section{Strategic coercion in bilateral and multilateral trade pacts}

The history of US free trade agreements is short. Only in 1985 did the US sign its first agreement with Israel followed by one with Canada three years later. Most US free trade agreements have been bilateral and signed in the early twentyfirst century. The Trump administration continued this longstanding bilateralism because they argued it played to US economic strength. Most of its agreements are with economies that are on average forty-four times smaller than its own (Ann Elliott 2017). Bilateralism was a means through which the US could exercise its hierarchy on its terms. These relationships allow US trade policy to continually use a tit-for-tat strategy against other states because Washington has thought that its strength lies in its ability to withstand more pressure and coercion than other states, whose economies are more precarious and more beholden to US economic demands.

The Trump administration instigated bilateral renegotiations of US-Japan trade and KORUS and expressed interest in developing bilateral trade relations with Brazil, the UK, and Kenya. In late 2020, 50 senators, many Republicans, and several Democrats pushed for the administration to instigate a trade deal with Taiwan. The rationale for this agreement was to reduce 'our [the US] reliance on other countries such as China who seek to leverage supply chain inefficiencies in their path to regional and global dominance' (US Senate 2020). Moreover, they remarked that Taiwan was a 'reliable' and 'like-minded' ally that has 'capacity to hold a strong economic partnership' with the US (ibid. 2020). Military and security interests were already invested in this relationship. The Trump administration sold $\$ 18$ billion worth of arms to Taiwan and made commitments to defend the country. The Biden administration has seemed to continue from this position (Sacks 2021).

Yet, there was also an oscillation in the USTR's comments about bilateral and multilateral trade pacts in the world economy. Lighthizer argued that "The FTAs, in my opinion, we should just get rid of them. We should have a multilateral system or a bunch of bilateral systems," this came as the US engaged in bilateral negotiations with Japan, China, the UK, and Kenya (Lawder and Shalal 2020). The context of his criticism was focused on the EU's proclivity for bilateral free trade agreements. He is consistent among several figures in the Trump administration and Congress who have chided the EU over its trade policy, and increasingly see the EU as an economic competitor (see Klein 2020). This incoherence about bilateralism is evidence of how the Trump administration struggled to find a way to realize its highly politicized strategic trade policy into a hierarchical, 
US-centric view of the world order. Indeed, Trump may not have even designed the tariff strategy as a permanent feature to block the free movement of goods and services but as a temporary threat to extract concessions from other states (Slobodian 2018a).

The US has consistently used coercion in NAFTA and USMCA to obtain preferable trade terms from two of its main trading partners. US congresses and administrations since 1994 have demanded that Mexico and Canada make trade concessions and remove unfair subsidies, even as the US used export subsidies. Washington, for instance, has repeatedly fought with Ottawa over subsidies for Canada's softwood lumber industry since the 1980s. Trump and Lighthizer's simultaneous withdrawal from the TPP and renegotiation of NAFTA demonstrates their desire to build a closer regional hierarchy through US-led economic integration. The administration and congress designed USMCA to support the US manufacturing industries and reduce the US trade deficit with Canada and Mexico. It opened the Canadian dairy market for US sellers and forced improvements to Mexican labor laws so American workers were not at such a competitive disadvantage. Nancy Pelosi remarked that once Canada and Mexico conceded to the demands of the House Democrats (after they conceded to the Trump administration) then the USMCA would be a "template for future trade agreements" (Politi and Sevastopulo 2019). The Trump administration was not rejecting globalization outright but reforming it to suit a set of strategic objectives about international hierarchy, secure supply chains and boosting exports.

The rise of China as a competitor did not mean that there was a bipartisan consensus that the US ought to be 'softer' with its allies to warmly encourage them into a US-led anti-China alliance. The administration's strategy and for many in Congress competition with China meant it had to ensure that more companies operated inside the US and that US corporations competed well against state-backed Chinese ones. It is with this rationale that the administration led the withdrawal from the TPP. The political consensus about the agreement was already breaking down in a narrow and polarized Senate. Republicans and Democrats in the 2010s pushed for a US withdrawal or major revisions to it. Democratic Party candidates had concerns about labor rights and standards across the Pacific (Steinhauer 2016). Republicans and corporations were troubled about legal protections. The tobacco lobby argued that because the agreement exempted antismoking measures from lawsuits it would lead foreign states to avoid them. Politicians and corporate lobbies were anxious that this would lead to a slippery slope of product restrictions of sugar, fats, and alcohol in future agreements and diminish the Investor-State Dispute Settlement (ISDS) process (Bollyky 2016). This declining political consensus about this free trade agreement being beneficial for the US slowed and eventually stopped Obama from forcing the deal through Congress. Thus, Trump's position on TPP was not such a wild outlier in the climate of opinion about free trade and integrating the US into trade multilateral pacts.

The US already had FTAs with six TPP signatories and was negotiating more access to the Japanese market in 2019. For the administration leaving TPP was not a cost, but an interpretation of how they thought the US should compete against rivals. It favored bilateral bargaining with the EU, Asian allies, and Canada and Mexico. 
The central objective of this strategy was to incentivize companies to come behind its tariff walls, and through forceful bilateral bargaining, secure access to foreign markets (Robinson 2019, 178).

Trump was not the first contemporary president to rethink US free trade agreements. There are echoes about it in the Clinton and Obama administrations. They did not adopt strategic trade with as much stridency, but the general argument in policy circles that states cheat or have not conceded enough to the US demands resonated. Clinton's deputy USTR Charlene Barshefsky described trade agreements after the Cold War. She said "with the Cold War over, trade agreements must stand or fall on their merits. They no longer have a security component. If we do not get reciprocity, we will not get freer trade" (Skålnes 2000, 198; Lewis 1996). This was not dissimilar to the 2019 Republican-led H.R.764 US Reciprocal Trade Act (H.R.764) in Congress that stipulated that the President should have a "wide array of tools" to prise open foreign markets for US goods. The Obama administration began to cooperate and compete with China in the early 2010s. He renegotiated parts of NAFTA and KORUS so the US could gain more market access to those nations (White House 2017). The Korean automotive market was a specific target of the Obama administration who rewrote the rules of the agreement to open its market for US auto companies. Obama and Trump harnessed the state apparatus to support American firms in the oligarchical international market. They interpreted that allies and China were cheating and attempting to usurp the competitiveness of American firms. This attitude of simultaneous coercion against allies and adversaries is not just a Trump phenomenon, even if his administration is particularly coercive and aggrieved about free trade agreements.

Lighthizer and Trump, among others, were not necessarily protectionist in a purist ideological manner but adopted protectionism strategically with free trade to advance their interpretation of US hierarchy in the world order. They were negotiating free-trade agreements with Kenya, Brazil, and the UK. Free trade is not analogous to a more benign form of internationalism or notions of liberal multilateralism among equal partners. What we see instead is a form of globalization that is more consistent with the US acting coercively to maintain hierarchy (see further de Orellana and Michelsen 2019; Drolet and Williams 2018; Slobodian 2018a). Lighthizer embodies the worldview premised on consolidating the US industry at home and increasing exports. His use of tariffs and export controls as legitimate instruments illustrate how the US attempts physically alter the political economy another states. This strategy is most clearly seen in Reagan and Trump who combined it with a competitive nationalism against military rivals, but there are fainter reproductions of it in other administrations.

\section{The Trump administration and the world trade organization}

The World Trade Organization (WTO) has been an arena for countries to bargain with one another and resolve disputes (Wilkinson 2017, 1135). Since its founding in 1995, successive US administrations have issued complaints and battled with allies 
over unfair trading. To win these cases, the USA has combined several trade instruments at the WTO to achieve consistent 'wins' for its domestic industries, it has however, lost some cases and has witnessed countries band together to complain against it. The fear of countries balancing power against the US at the WTO has come to particular attention (Nelson 2019). The Trump administration's general strategy at the WTO was one of belligerency to carve out a more zero-sum hierarchical structure in world trade. In doing so, the administration has partly challenged the Republican Party's orthodoxy of supporting free trade rhetoric and the effectiveness of the WTO in supporting US trade.

The US Trade Representative (USTR) office was the central actor in the display and practiced of a politicized strategic trade policy at the WTO. Trump's USTR Robert Lighthizer publicly criticized the trade body as damaging to US interests (Lighthizer 2020b; Swanson 2020). This was not out of character or an unlikely strategy. There was significant bipartisan support in his 82-14 confirmation in the Senate despite polarization between the administration and Senate Democrats. At his confirmation hearing, Republicans and Democrats praised his experience, his robust enforcement of trade laws, and his priority to protect US manufacturers and workers (US Senate 2017). Although he had a high profile for a USTR during significant trade renegotiations, Lighthizer served a full four years.

Moreover, he was one of the administration's direct links with the Reagan administration -he served in it as deputy USTR from 1983 to 85 before becoming a steel lobbyist in Washington until Trump hired him. As Reagan's deputy USTR in 1983, Lighthizer threatened Japan with steep tariffs and export controls if they continued to export cheap steel to the US. He activated an underlying discourse in US trade circles about the economic threat of cheap Japanese imports and the loss of American manufacturing (see further Miller 2018; Slobodian 2018b). Reorganizing the WTO and curtailing China's behavior in international trade was the new challenge, as Japan and its firms had been largely subsumed into the US hierarchy.

Lighthizer's strategy was unsentimental toward the WTO and the idea of creating a more even international trade system. The US ceased nominating judges to the WTO's Appellate Body to damage its dispute resolution abilities in the hope of enhancing US coercion of the WTO and members. Lighthizer and Dennis Shea used this tactic so the WTO would look more like GATT. They explicitly wanted to reset the organization over tariff issues to discipline China (Williams 2020). Their thinking was in tune with some insurgent thinking in the Republican Party. Senator Josh Hawley advocated abolishing the WTO, and other Republicans have favored withdrawing from global regulating bodies, from the World Health Organization to arms treaties, and various other UN treaties (see Weiss et al. 2019; Cotton 2019; Hawley 2020).

The Republican Party has been largely wedded to free trade in rhetoric since at least the 1980s. But the party, along with the Democratic Party, has primarily organized trade policy to assert American dominance in the world order through the subordination of allies and adversaries. For many Republicans, this strategic attitude aligned with free trade. At other times, however, Trump, Lighthizer, Navarro, and Shea, along with some in the Republican Party, sought to hone a protectionist, interventionist or more coercive trade strategy. In their perspective, China's recent power 
meant it would assert greater influence in the institutions of global governance, such as the WTO (Kennedy 2017). Trump, Navarro, and Lighthizer's penchant for protectionism caused some disharmony among free trade supporting Republicans in Congress, but these disagreements were about tactical emphasis rather than objective.

Although free trade was a deep ideological belief among party members, it did not exclude them from arguing in favor of the US intensifying its complaint procedure at the WTO and demanding reciprocal trade from allies and partners through any means. Their attachment to free trade is not as an abstract economic theory but as a method to enhance US power. The administration, along with Republican Party, continued to play on a common theme that pushed allies to open their markets (Weiss et al. 2019, 501; Fehl and Thimm 2019). This approach is like how Reagan strategically used free trade and other instruments to coerce allies into conforming with the US-led hierarchy. This is not to argue that Republican support for free trade is merely rhetorical, but it is one paradigm among others that jostle to achieve the objective of US international dominance in trade. Lighthizer made this explicit in his Trade Policy Agenda in 2018 which sought to achieve "free, fair, and reciprocal" trade (Lighthizer 2020a).

There were intra-Republican Party disagreements about whether the US should play an active role in global governance or be more skeptical about international institutions. This was reflected in how the administration's policies appeared to work at cross purposes. The administration used the WTO to lodge complaints about allies and China even as it criticized the WTO compliance structure (Salama 2018; Swanson 2017). Lighthizer's approach was to seek an overhaul of the WTO to favor rich states and subordinate poorer ones or states with non-market economies. He argued that states ought to reduce their tariffs or face sustained US tariff hikes on their exports (Hufbauer and Jung 2020). The Republican-led (27 co-sponsors) Reciprocal Trade Act of 2019 in Congress demanded that WTO members reduce their tariffs, so the US could export more to them (H.R.764, 2019). Republican Lindsey Graham and Democrat Joe Manchin sponsored a related bill in the Senate. This demand for reciprocity is not an expression of liberal internationalism through 'fair trade,' but is instead a strategic instrument that the US attempted to wield for competitive advantage against other states because the material gap between them is so far.

Trump's rhetorical hostility about trade departs from Obama, but both administrations shared a discontentment about the WTO. Obama's second USTR Michael Froman sought a new chapter for the WTO to reflect 'today's economic realities,' and to accept that states will not accept agreements that are 'a single undertaking' (Froman 2015 in Wilkinson 2017, 1133). In this view, the trade body should allow greater flexibility in agreements. This would mean some states could have optouts to protect certain industries. The Obama administration directed sixteen of its twenty-five complaints at the WTO against China (White House 2017). Most concentrated on unfair subsidies, export restrictions for the US-made products, and poor import duty infrastructure. His administration used the WTO compliance structure to benefit US trade and secured legislative and executive authority to upgrade the government's ability to enforce trade standards. Trump favored an illiberal worldview that prioritized coercion as a strategy and was disparaging of the benefits of liberal internationalism to the USA, but this ultimately had the same objective. 


\section{Conclusion}

This article has sought answers to questions about the development of what appears to be incoherent and mismatched trade instruments, and why the US under Trump coerced its allies even as it pointed to existential threats from China in the 2010s. Furthermore, Reagan and Trump have used strategic trade policy to define a different form of internationalism-one that is based on US supremacy as the main driver of global economic growth. The paper has argued that the Trump administration has not been a full-scale departure from all previous administrations. Instead, it fits into the broad strategic thought that existed in the USA from the 1980s. His rhetoric and ill-prepared policies have been divisive among Republicans and Democrats, and many allies, but there is a common objective and strategic vision. The administration has attempted to reshore manufacturing jobs to the USA and shift importing goods from China to other Asian countries, notably Vietnam (Kearney 2020). It has strategically used subsidies to support domestic agriculture and some manufacturing industries. The purpose of the strategy was to grow the US' technological-industrial base so it could compete in Great Power rivalry.

This intellectual, legislative, political, and strategic milieu may perhaps determine what kind of actor the US is going to be as the world becomes more polycentric and if competition intensifies with China. A more multipolar world does not necessarily equate to more multilateralism (see Makarychev and Morozov 2011; Laïdi 2014; Fehl and Thimm 2019). US allies often clashed with Trump's behavior and policies. His political style certainly stressed trans-Atlantic and Pacific relations. But for the administration, these relations were of secondary importance when compared to rebuilding manufacturing industries and securing supply chains in the USA. They were willing to risk, even dismiss, diplomatic relations and a liberal view of globalization so the US could be competitive. Trump channeled an intense and deeply political strategic trade policy that originated in the 1980s into the 2010s so the US could 'win' against China, the WTO, and its industrialized allies on trade. The Biden administration has to date kept tariffs on China, and threatened several allies with tariffs if they went ahead with planned taxes on US technology firms. Notably, the Senate voted 98-0 for Katherine Tai to be the new USTR in part because of her stances on China and trade competition.

Finally, Trump's strategy was not a redux of the so-called foreign policy isolationism in the 1930s. It is a distinctly latter twentieth-century American solution that comes from a national political class that found US global dominance at existential risk in what it thinks is an increasingly polycentric world (see Jentleson 2017; Acharya 2018). The administration's vision of globalization attempts to reform and remake the architecture of supranational organizations and global norms to enhance American power. They directly overturned the optimism that globalization could be a grand narrative where states and non-state actors gather to benignly promote peace and prosperity. As this article shows, US strategic trade policy has a variety of instruments: strategically erecting and discarding tariffs and free trade measures; supporting domestic firms with subsidies and 
deregulation whilst lodging complaints about foreign governments who do the same; supporting supranational and multilateral bodies and crippling or abandoning other global institutions. These instruments define a form of globalization that attempts to activate an explicit US-led hierarchy.

\section{Declarations}

Conflict of interest The author hereby states that there are no conflicts of interest. Any errors of fact or reasoning are the author's sole responsibility.

\section{References}

Acharya, A. 2018. The End of American World Order. (UK, Polity).

Ann Elliott, K. 2017. Is Bilateralism the Future of US Trade Policy? Should it be? Washington International Trade Association. https://www.wita.org/blogs/is-bilateralism-the-future-of-us-trade-policyshould-it-be/. Retrieved 22 July 2020.

Bhagwati, J., and H.T. Patrick. 1991. Aggressive Unilateralism: America's 301 Trade Policy and the World Trading System. Ann Arbor, MI: University of Michigan Press.

Blinken, A. 2017. Trump Is Ceding Global Leadership to China. The New York Times. 8 November 2017. https://www.nytimes.com/2017/11/08/opinion/trump-china-xi-jinping.html. Retrieved 4 February 2021.

Bollyky, T. 2016. TPP Tobacco Exception Proves the New Rule in Trade. Council on Foreign Relations. https://www.cfr.org/expert-brief/tpp-tobacco-exception-proves-new-rule-trade. Retrieved 22 July 2020.

Boyd, G. 1987. President Imposes Tariff on Imports Against Japanese. The New York Times. https:// www.nytimes.com/1987/04/18/business/president-imposes-tariff-on-imports-againstjapanese.html. Retrieved 22 July 2020.

Brander, J., and B. Spencer. 1983. International R\&D Rivalry and Industrial Strategy. Review of Economic Studies 50 (4): 707-722.

Brander, J., and B. Spencer. 1985. Export Subsidies and International Market Share Rivalry. Journal of International Economics 18 (1-2): 83-100.

Brander, J. 1995. Rationales for Strategic Trade and Industrial Policy. In Strategic Trade Policy and the New International Economics Cambridge, ed. P. Krugman. MA: MIT Press.

Brody, K. 1998. Building American Prosperity in the 21st Century: U. S. Trade and Investment in the Asia Pacific Region. Collingdale, PA: Diane Publishing.

Clines, F. 1983. Reagan Cautions Japan Over Trade. The New York Times. January 20, 1983, page A1.

Cotton, T. 2019. The Open Skies Treaty is Giving Russia Spying Capabilities. End It. The Washington Post. https://www.washingtonpost.com/opinions/2019/12/10/open-skies-treaty-isgiving-russia-spying-capabilities-end-it/. Retrieved 10 July 2020.

Dian, M. 2017. The Strategic Value of the Trans-Pacific Partnership and the Consequences of Abandoning it for the US Role in Asia. International Politics 54: 583-597.

Department of Defense. 2018. Assessing and Strengthening the Manufacturing and Defense Industrial Base and Supply Chain Resiliency of the United States. Office of the Under Secretary of Defense for Acquisition and Sustainment \& Office of the Deputy Assistant Secretary of Defense for Industrial Policy.

Dreiling, M., and D. Darves. 2011. Corporate Unity in American Trade Policy: A Network Analysis of Corporate-Dyad Political Action. American Journal of Sociology 116 (5): 1514-1563.

Drolet, J., and M.C. Williams. 2018. Radical Conservatism and Global Order: International Theory and the New Right. International Theory 10 (3): 285-313.

Eaton, J. 1995. Credit Policy and International Competition. In Strategic Trade Policy and the New International Economics, ed. P. Krugman. Cambridge, MA: MIT Press.

Farnsworth, C. 1983. Reagan May Raise Ex-Im Bank Funds. The New York Times. 27 January 1983, page D2. 
Fehl, C., and J. Thimm. 2019. Dispensing With the Indispensable Nation? Global Governance. 25 (1): 23-49.

Froman, M. 2015. We are at the End of the Line on the Doha Round of Trade Talks. Financial Times. December 15, 2015. https://www.ft.com/content/4ccf5356-9eaa-11e5-8ce1-f6219b685d74. Retrieved 29 June 2020.

Hawley, J. 2020. The W.T.O. Should Be Abolished. The New York Times. May 5, 2020. https://www. nytimes.com/2020/05/05/opinion/hawley-abolish-wto-china.html. Retrieved March 102020.

Herbert, J., T. McCrisken, and A. Wroe. 2019. The Ordinary Presidency of Donald J. Trump. UK: Palgrave.

H.R.764 United States Reciprocal Trade Act. (2019). 116th Congress, https://www.congress.gov/bill/ 116th-congress/house-bill/764/related-bills. Retrieved 3 February 2021.

Hufbauer, G. and E. Jung. 2020. USTR Lighthizer's great leap backward on trade. Peterson Institute for International Economics, 1 September 2021. https://www.piie.com/blogs/trade-and-investment-policy-watch/ustr-lighthizers-great-leap-backward-trade. Retrieved 3 February 2021.

Institute of Export \& International Trade. 2020. 'Rehoming' Supply Chains: US Will Pay for Companies to Relocate Back Home from China. Institute of Export \& International Trade. https://www.export. org.uk/news/509609/Rehoming-supply-chains-US-will-pay-for-companies-to-relocate-back-homefrom-China.htm. Retrieved 11 February 2021.

Jentleson, B. 2017. Global Governance, the United Nations, and the Challenge of Trumping Trump. Global Governance 23 (2): 143-149.

Kearney. 2020. Reshoring Index. Kearney. https://www.kearney.com/operations-performance-transforma tion/us-reshoring-index. Retrieved 24 July 2020.

Kennedy, S. 2017. Global Governance and China the Dragon's Learning Curve. Abingdon, Oxon: Routledge.

Klein, B. 2020. America's Trade Chief Has a Bold New Plan. U.S. Companies, Beware. Barron's. 14 September 2020. https://www.barrons.com/articles/americas-trade-chief-has-a-bold-new-plan-u-scompanies-beware-51600088031. Retrieved 3 February 2021.

Krugman, P., ed. 1995. Strategic Trade Policy and the New International Economics. Cambridge, MA: MIT Press.

Laïdi, Z. 2014. Towards a Post-Hegemonic World: The Multipolar Threat to the Multilateral Order. International Politics 51 (3): 350-365.

Lawder, D. and A, Shalal. 2020. USTR Lighthizer Says Bilateral Trade Pacts Conflict with Multilateral Trading System. Reuters. July 9, 2020. https://www.reuters.com/article/us-usa-trade-lighthizer/ustrlighthizer-says-bilateral-trade-pacts-conflict-with-multilateral-trading-system-idINKBN24A2VG? edition-redirect=in. Retrieved 3 February 2021.

Lewis, P. 1996. Is the U.S. Souring on Free Trade? The New York Times. https://www.nytimes.com/1996/ 06/25/business/is-the-us-souring-on-free-trade.html. Retrieved 24 July 2020.

Lighthizer, R. 2020a. "2019 Trade Policy Agenda and 2018 Annual Report of the President of the United States on the Trade Agreements Program." United States Trade Representative Office.

Lighthizer, R. 2020b. How to Make Trade Work for Workers. Foreign Affairs. July/August 2020. https:// www.foreignaffairs.com/articles/united-states/2020-06-09/how-make-trade-workworkers. Retrieved 8 February 2021.

Makarychev, A., and V. Morozov. 2011. Multilateralism, Multipolarity, and Beyond: A Menu of Russia's Policy Strategies. Global Governance. 17 (3): 353-373.

Meijer, H. 2020. Shaping China's rise: The reordering of US alliances and defence partnerships in East Asia. International Politics. 57: 166-184.

Meinderts, T. 2020. The Power of Section 301: The Reagan Tariffs in an Age of Economic Globalization. Globalizations 17 (4): 746-758.

Miller, J.M. 2018. Let's Not be Laughed at Anymore: Donald Trump and Japan from the 1980s to the Present. Journal of American-East Asian Relations. 25 (2): 138-168.

National Intelligence Council. 1982. The United States in the World Economy: Elements of Strength. National Intelligence Council Memorandum.

Nelson, D. 2019. Facing Up to Trump Administration Mercantilism: The 2018 WTO Trade Policy Review of the United States. The World Economy. 42 (12): 3430-3437.

Noble, K. 1984. U.S. Export Aid for Central America. The New York Times. December 20, 1984. p. D 23.

Nollen, S., and D. Quinn. 1994. Free Trade, Fair Trade, Strategic Trade, and Protectionism in the U.S. Congress, 1987-88. International Organization. 48 (3): 491-525. 
de Orellana, P., and N. Michelsen. 2019. Reactionary Internationalism: The Philosophy of the New Right. Review of International Studies 45 (5): 748-767.

Pamuk, H. and A. Shalal. 2020. Trump Administration Pushing to Rip Global Supply Chains from China: Officials. Reuters, 4 May 2020. https://www.reuters.com/article/us-health-coronavirus-usa-china/ trump-administration-pushing-to-rip-global-supply-chains-from-china-officials-idUKKBN22G0BZ. Retrieved 4 February 2021.

Pence, M. 2018. Mike Pence's Remarks on the Administration's Policy Towards China. Hudson Institute. 4 October 2018. https://www.hudson.org/events/1610-vice-president-mike-pence-s-remarks-on-theadministration-s-policy-towards-china102018. Retrieved 3 February 2021.

Politi, J. and D. Sevastopulo. 2019. Nancy Pelosi Willing to Allow Vote on Nafta Revamp. The Financial Times, October 31 2019. https://www.ft.com/content/57556b04-fbf7-11e9-a354-36acbbb0d9b6. Retrieved 3 March 2021.

Rajah, R. 2018. American Trade Policy Returns to "Aggressive Unilateralism". The Lowy Institute. https://www.lowyinstitute.org/the-interpreter/american-trade-policy-returns-aggressiveunilateral ism. Retrieved 22 July 2020.

Rice, S. 2017. Susan Rice: Trump Is Making China Great Again? The New York Times, November 13, 2017. https://www.nytimes.com/2017/11/13/opinion/susan-rice-trump-china-trip.html. Retrieved 3 March 2021.

Richardson, J. 1990. The Political Economy of Strategic Trade Policy. International Organization. 44 (1): $107-135$.

Robinson, W. 2019. Global Capitalist Crisis and Twenty-First Century Fascism: Beyond the Trump Hype. Science \& Society 83 (2): 155-183.

de Rugy, V. 2014. Export-Import Bank Defenders Rely on Ronald Reagan to Save its Funding. Mercatus. May 8, 2014. https://www.mercatus.org/expert_commentary/export-import-bank-defenders-relyronald-reagan-save-its-funding. Retrieved 11 February 2021.

Rushing, F. 2020 [1990]. Intellectual Property Rights in Science, Technology, And Economic Performance: International Comparisons (New York, NY: Routledge).

Sacks, D. 2021. Biden Administration Sends Important Signals for the Future of U.S.-Taiwan Ties. Council on Foreign Relations. 28 January 2021. https://www.cfr.org/blog/biden-administration-sendsimportant-signals-future-us-taiwan-ties. Retrieved 5 February 2021.

Salama, V. 2018. U.S. Files Complaints With WTO Against Trading Partners. The Wall Street Journal. July 16, 2018. https://www.wsj.com/articles/u-s-files-complaints-with-wto-against-trading-partners1531767528. Retrieved 3 February 2021.

Schwarzenberg, A. 2020a. Section 301 of the Trade Act of 1974. Congressional Research Service. https:// crsreports.congress.gov/product/pdf/IF/IF11346. Retrieved 30 October 2020.

Schwarzenberg, A. 2020b. Section 301 of the Trade Act of 1974: Origin, Evolution, and Use. Congressional Research Service. https://fas.org/sgp/crs/misc/R46604.pdf. Retrieved 7 February 2021.

Segawa, N. 2020. Japan Excluded from New US Foreign Investment Whitelist. Nikkei Review.

Shalal, A., Alper, A. and P. Zengerle. 2020. U.S. Mulls Paying Companies, Tax Breaks to Pull Supply Chains from China. Reuters. May 18, 2020. https://www.reuters.com/article/us-usa-china-supplychains-idUSKBN22U0FH. Retrieved 9 February 2021.

Shea, D. and Bartholomew, C. 2016. Ban China's State Firms From Acquiring U.S. Companies. The Wall Street Journal. https://www.wsj.com/articles/ban-china-s-state-firms-from-acquiring-u-s-compa nies-1481218933. Retrieved 8 February 2021.

Skålnes, L. 2000. Politics, Markets, and Grand Strategy: Foreign Economic Policies as Strategic Instruments. Ann Arbor, MI: University of Michigan Press.

Slobodian, Q. 2018a. Trump, Populists and the Rise of Right-Wing Globalization. The New York Times. https://www.nytimes.com/2018/10/22/opinion/trump-far-right-populists-globalization.html. Retrieved 8 July 2020.

Slobodian, Q. 2018b. You Live in Robert Lighthizer's World Now. Foreign Policy. https://foreignpol icy.com/2018/08/06/you-live-in-robert-lighthizers-world-now-trump-trade/. Retrieved 12 February 2021.

Smith, C. 2011. Trade Promotion Authority and Fast-Track Negotiating Authority for Trade Agreements: Major Votes. Congressional Research Service. https://fas.org/sgp/crs/misc/RS21004.pdf. Retrieved 10 July 2020.

Stegemann, K. 1989. Policy Rivalry among Industrial States: What Can We Learn from Models of Strategic Trade Policy? International Organization. 43 (1): 73-100. 
Steinhauer, J. 2016. Both Parties Used to Back Free Trade. Now They Bash It. The New York Times. July 29, 2016. https://www.nytimes.com/2016/07/30/us/politics/in-time-of-discord-bashing-trade-pactsappeals-to-both-parties.html. Retrieved March 12, 2021.

Swanson, A. 2017. U.S. Joins Europe in Fighting China's Future in W.T.O. The New York Times. https:// www.nytimes.com/2017/11/29/us/politics/china-us-trade-wto.html. Retrieved 22 July 2020.

Swanson, A. 2020. Trump Trade Official Defends China Deal and Criticizes the W.T.O. The New York Times. https://www.nytimes.com/2020/06/17/business/economy/us-trade-chinatariffs.html. Retrieved 22 July 2020.

Swanson, A. and T. Kaplan. 2017. Senate Panel Rejects Trump's Nominee to Lead Export-Import Bank. The New York Times. December 17, 2017. https://www.nytimes.com/2017/12/19/us/politics/repub licans-senate-export-import-bank-trump.html. Retrieved 11 February 2021.

Tankersley, J. 2018. Steel Giants with Ties to Trump Officials Block Tariff Relief for Hundreds of Firms. The New York Times. August 5, 2018. https://www.nytimes.com/2018/08/05/us/politics/nucor-ussteel-tariff-exemptions.html. Retrieved 11 February 2021.

Trump, D.J. 1987. There's Nothing Wrong with America's Foreign Defense Policy That a Little Backbone Can't Cure. September 2, 1987. The New York Times. A28.

Tuathail, G.Ó. 1996. Critical Geopolitics: The Politics of Writing Global Space. London: Routledge.

US Congress. 1984. Summary of Provisions of H.R. 3398, Trade and Tariff Act of 1984 as Passed. US Congress: House Committee on Ways and Means. (US Government Printing Office).

US Senate. 2017. Hearing to Consider the Nomination of Robert Lighthizer, of Florida, to be United States Trade Representative, with the rank of Ambassador Extraordinary and Plenipotentiary. United States Senate Committee on Finance. March 14, 2017.

US Senate, 2020. Risch, Inhofe, Menendez, Colleagues Urge Lighthizer to Begin Talks for a Trade Agreement with Taiwan. US Senate Committee on Foreign Relations, 1 October 2020. https://www. foreign.senate.gov/press/chair/release/risch-inhofe-menendez-colleagues-urge-lighthizer-to-begintalks-for-a-trade-agreement-with-taiwan. Retrieved 5 February 2021

Vernon, R. 1982. International Trade Policy in the 1980s: Prospects and Problems. International Studies Quarterly 26 (4): 483-510.

Warmbrodt, Z. 2019. Conservatives Challenge Trump Push to Resurrect Export Bank. Politico. May 6, 2019. https://www.politico.com/story/2019/05/06/conservatives-trump-export-import-bank-14086 51. Retrieved 11 February 2021.

Waterhouse, B.C. 2014. Lobbying America: The Politics of Business from Nixon and NAFTA. Princeton, NJ: Princeton University Press.

Weinraub, B. 1985. Reagan Proposes Export Subsidies to Gain Markets. The New York Times. September 24, 1985. A1.

Weiss, T.G., D.P. Forsythe, and R.A. Coate. 2019. The United States, the UN, and New Nationalisms Old Truths, New Developments. Global Governance 25 (4): 499-508.

The White House. 2017. Factsheet: The Obama Administration's Record on the Trade Enforcement. The White House. https://obamawhitehouse.archives.gov/the-pressoffice/2017/01/12/fact-sheet-obamaadministrations-record-trade-enforcement. Retrieved 22 July 2020.

Wilkinson, R. 2017. Back to the Future: 'Retro' Trade Governance and the Future of the Multilateral Order. International Affairs 93 (5): 1131-1147.

Williams, A. 2020. Top Trade Official says US Will Seek 'Broader Reset' of WTO Tariffs. The Financial Times. https://www.ft.com/content/00cdebfa-e364-4914-a629-29f1fdd290ff. Retrieved 8 February 2021.

Wraight, T. 2019. From Reagan to Trump: The Origins of US Neoliberal Protectionism. Political Quarterly 90 (4): 735-742.

Wren, C. 1983. China, Upset by U.S. Trade Curb, Halting Imports of 3 Commodities. The New York Times. January 20, 1983, page A1.

Zanchetta, B. 2015. Deconstructing 'Declinism': The 1970s and the Reassertion of American International Power. International Politics. 52: 269-287.

Zarakol, A. 2019. 'Rise of the Rest': As Hype and Reality. International Relations. 33 (2): 213-228.

Publisher's Note Springer Nature remains neutral with regard to jurisdictional claims in published maps and institutional affiliations. 